\title{
Comparing morphology and physiology of southeastern US Pinus seedlings: implications for adaptation to surface fire regimes
}

\author{
Lauren S. Pile ${ }^{1,2} \cdot$ G. Geoff Wang ${ }^{1} \cdot$ Benjamin O. Knapp ${ }^{3} \cdot$ Guohua Liu $^{4} \cdot$ Dapao $\mathrm{Yu}^{5}$
}

Received: 9 May 2017 / Accepted: 2 October 2017 /Published online: 16 October 2017

(C) INRA and Springer-Verlag France SAS 2017

\begin{abstract}
- Key message The suite of traits expressed as seedlings by coastal and mountain longleaf pine and south Florida slash pine suggest they can survive fire in the seedling stage. In contrast, loblolly pine and typical slash pine tolerate fire when mature but do not exhibit traits that allow them to survive fire when young, representing a different strategy for survival in frequently burned communities.

- Context Fire is an important driver in the distribution and abundance of southern US pine species, and seedling fire tolerance often determines individual survival under frequent fire regimes.
\end{abstract}

Handling Editor: Andrew Merchant

Contribution of the co-authors LSP: research idea development, greenhouse applications, data analysis, preparing the manuscript; GGW: research idea initiation and development, experimental design, contribution to manuscript; $\mathrm{BOK}$ : contribution to manuscript, collaboration in data analysis; GL: laboratory work; DY: greenhouse applications.

Electronic supplementary material The online version of this article (https://doi.org/10.1007/s13595-017-0666-6) contains supplementary material, which is available to authorized users.

G. Geoff Wang

gwang@clemson.edu

Lauren S. Pile

lpile@fs.fed.us

Benjamin O. Knapp

knappb@missouri.edu

Guohua Liu

ghliu@njfu.edu.cn

Dapao Yu

yudp2003@iae.ac.cn
- Aims We investigated seedling growth, biomass allocation, needle distribution, bark thickness, and total non-structural carbohydrate (TNC) storage in taproots and related them to the expression of fire-tolerance for five species or types, including loblolly pine (Pinus taeda L.), two longleaf pine (P. palustris Mill.) types representing two distinct ecological communities (coastal and mountain) and two slash pine (P. elliottii Englem.) varieties.

- Methods We analyzed the relationship of seedling growth, biomass characteristics, and total non-structural carbohydrate storage between species by using analysis of variance.

- Results Both coastal and mountain longleaf pines had thick bark, long, densely arranged needles, and a grass-stage. South Florida slash pine shared the same suite of traits but, contrary to previous reports, displayed reduced height growth rather than a grass-stage. In contrast, loblolly pine and typical slash pine had faster height growth, more branching, lower needle density, and thinner bark. Both longleaf pines and south Florida slash pine also had higher TNC storage in taproots than either loblolly or typical slash pines.

- Conclusion The relative strength of expression of these fireadaptation traits among the five species types generally

1 Department of Forestry and Environmental Conservation, Clemson University, Clemson, SC 29634, USA

2 Present address: USDA Forest Service, Sierra National Forest—-High Sierra Ranger District, Prather, CA 93651, USA

3 School of Natural Resources, University of Missouri, 203 Anheuser-Busch Natural Resources Building, Columbia, MO 65211, USA

4 Bamboo Research Institute, Nanjing Forestry University, Nanjing 210037, China

5 Institute of Applied Ecology, Chinese Academy of Sciences, Shenyang 110016, China 
matches the fire-return intervals associated with each species' habitat, suggesting the importance of fire regimes in determining the distribution and abundance of the studied species.

Keywords Mountain longleaf · South Florida slash pine · Fire-tolerance $\cdot$ Total non-structural carbohydrate $\cdot$ Bark thickness

\section{Introduction}

The evolution of the genus Pinus has been closely linked to fire regimes and site conditions, with the divergence of the subgenera Strobus (Haploxylon, with one fibrovascular bundle in the needle) and Pinus (Diploxylon, with two fibrovascular bundles in the needle) broadly associated with tolerance of abiotic stress and tolerance of fire, respectively (Keeley 2012; Millar 1998). Species within the subgenus Strobus (e.g., P. flexilis James, P. aristata Engelm.) have been described as "fire-avoiders," whereas those within the Pinus subgenus are further differentiated as "fire-tolerators" (e.g., P. pinaster Aiton), "fire-embracers" (e.g., P. contorta Douglas ex Loudon), and "fire-refugia" species (e.g., P. sabiniana Douglas ex Douglas) (Keeley and Zedler 1998). Traits of fire-tolerators may include thick bark, a seedling grass-stage, protected buds, and canopy recovery from scorch, which allows individuals to survive during fire and are often associated with frequent, low- to moderateintensity fire regimes (Keeley 2012). Traits associated with fire-embracers may include serotiny, seed germination after fire, sprouting capacity, and fast initial growth, which may allow the species to successfully regenerate after fire and are often associated with less frequent but high-intensity fire regimes (Keeley and Zedler 1998). Fire-refugia species fit into neither of the other two syndromes but act as the source population for expansion following fire (Keeley 2012).

The southeastern USA is generally characterized by frequent, low-intensity, surface fires (Brown and Smith 2000), and fire-adaptive traits of seedlings are especially important for defining the regeneration strategies under a frequent surface fire regime (e.g., O'Brien et al. 2008). However, even within fire frequent surface ecosystems, fire-return intervals may vary in relation to site productivity, species composition, regional climatic variability, and topo-edaphic factors. Once they reach maturity, pines are commonly protected from surface fire by thick bark, crown height, and self-pruning. However, seedlings and saplings are directly exposed to surface fires and thus more vulnerable to mortality (Keeley 2012). The frequency of fire within a community type may be expressed by the fire-adaptive traits of pine seedlings that occupy a particular fire regime.

Several morphological and physiological traits during the seedling stage may be associated with fire-tolerance in frequent fire ecosystems. For example, for species that have a grass-stage, the seedlings have minimal stem elongation but produce a tuft of needles surrounding the apical bud at the ground surface. Growth during this stage is allocated to foliage, root development, belowground carbon storage, and stem/bark development at the root collar (O'Brien et al. 2008). It has been speculated that the storage of nonstructural carbohydrates in the roots provides energy for regrowth of foliage following fire consumption and/or rapid height growth as seedlings emerge from the grass-stage (Guo et al. 2004; Kuehler et al. 2006; Mims 2015). Additionally, the development of thick bark in seedlings provides protection from heat exposure to the cambial tissue, with evidence that patterns in bark thickness at broad scales are associated with evolutionary pressure from fire (Pausas 2015).

Of the dominant southeastern US pine species, longleaf pine (P. palustris Mill) is considered the most fire-tolerant because of its grass-stage, long needles that protect the apical bud, and thick bark. Longleaf pine occurs within several ecoregions across the southeastern USA, with the greatest extent occurring within Coastal Plain ecoregions. However, a relatively small portion of the longleaf pine range occurs within the Piedmont and Montane Uplands ecoregion in northern Alabama and Georgia (Peet 2006). Despite clear differences in topo-edaphic characteristics between the Piedmont and Montane Uplands ecoregion and Coastal Plain ecoregion, it is not clear if longleaf pine seedling traits differ by ecoregion. Slash pine (P. elliottii) is characterized by two varietals (slash pine: var. elliottii Englem. and south Florida slash pine: var. densa Little and Dorman) based on ecological region and clinal variation (Squillace 1966). South Florida slash pine is considered more fire-tolerant than typical slash pine and expresses several fire-adaptive traits similar to longleaf pine, including thick bark and a documented grassstage (Lohrey and Kossuth 1990). Typical slash pine is vulnerable to fire when young but becomes more fire-tolerant with age as trees develop thick bark and high open crowns. Similar to typical slash pine, loblolly pine (P. taeda L.) is susceptible to fire in early life stages but may survive surface fire as tree size increases. The ranges of these species and their associated site characteristics overlap (Online Resource 1), suggesting that differences in fire regime may be a critical driver of pine dominance in the southeastern USA (Frost 2006; Schultz 1999).

The purpose of our study was to determine differences in morphological and physiological fire-adapted traits among three common southeastern US pine species (i.e., loblolly, longleaf, and slash pine) under controlled greenhouse conditions. We studied five species types, including longleaf pine seedlings from the two ecoregions (Atlantic Coastal Plain, referred to as "coastal" and Piedmont and Montane Uplands, referred to as "mountain"; Peet 2006), both slash pine varieties (referred to as "typical" and "south Florida" slash pines) and loblolly pine. Our specific objectives were to (1) compare patterns in growth, biomass allocation, and needle distribution 
along the stem, bark thickness, and total non-structural carbohydrate (TNC) concentration in taproots among the five species types and (2) relate morphology and physiology to the expression of seedling fire-tolerance traits among these species types. Specifically, we used the seedling data collected to develop simple indices to quantitatively express five commonly described fire-tolerator traits (Table 1). Grass-stage seedlings delay stem elongation but increase root collar diameter (RCD), and we used the ratio of RCD to height as an expression of the grass-stage (1). Bark thickness provides an important measure of meristem protection and was represented as the proportion of basal area (ba) in bark to the proportion of basal area in wood (2). Self-pruning reduces the risk of crown consumption and scorch, which we expressed as the inverse of branch biomass (3). Root TNC may contribute to recovery following foliar consumption during fire and was expressed as the TNC concentration (4). The consumption of needles may affect fire behavior by increasing the rate of fire spread as well as deflecting heat from the meristematic tissues, and we used the ratio of needle biomass to total seedling biomass to express needle allocation (5). We hypothesized that the two longleaf pine types and south Florida slash pine would express traits associated with surviving frequent fire while typical slash pine and loblolly pine would express traits associated with rapid growth to escape damage from the next fire.

\section{Materials and methods}

\subsection{Seed source}

Loblolly pine (coastal SC origin) seeds and coastal longleaf pine seeds were provided by South Carolina Forestry Commission's (SCFC) Taylor Tree Nursery (Trenton, SC). Mountain longleaf pine seeds were collected from mature mountain naturally regenerated longleaf pine stands at Berry College in Floyd County,
Georgia. Slash pine seeds, both typical and South Florida varieties, were provided by Florida Forest Service's Andrews Nursery.

\subsection{Seedling culture in greenhouse}

Seedling culture was conducted at the Clemson University greenhouse in Clemson, South Carolina. Seeds of each species type were planted according to standard tree nursery propagation methods from SCFC Taylor Tree Nursery. Initial planting occurred April 18 and 212014 (time of planting or month 0 ; "M0"). Seeds were sown on a mixture of $40 \%$ peat, $40 \%$ coarse vermiculite, and $20 \%$ horticultural grade perlite and covered lightly with vermiculite. Trays were fertilized with 18-6-12 Osmocote ${ }^{\circledR}$ (The Scotts Company, Marysville, $\mathrm{OH}$ ) slow release fertilizer with 9month residual and applied at a rate of $3.56 \mathrm{~kg} / \mathrm{m}^{3}$. Pots were watered daily. After seed germination and initial growth, due to space constraints for the accommodation of larger pot sizes, a population of 30 (25 for loblolly pine and coastal longleaf pine due to initial mortality) of the best-performing seedlings per species type $(n=140)$ were used for the study. The seedlings transplanted to 0.5 -gal (1.9-1) nursery trade pots on July 18, 2014. On January 9, 2015, seedlings were transplanted into 1-gal (3.8-1) nursery trade pots and fertilized with Osmocote .

\subsection{Data collection}

We conducted initial measurements of seedling size (RCD and height) on August 23, 2014 (5 months after planting; "M5"), after the first transplanting. The two subsequent measurements were conducted on January 6, 2015 ("M9") and May 20, 2015 (“M13”). RCD was measured using digital calipers (0.01 mm accuracy), and height was measured with a meter stick (1 cm accuracy).

Table 1 Fire-tolerance traits and how the trait is expressed as derived through measurement

\begin{tabular}{|c|c|c|c|}
\hline Trait & Description & Expression & Citations \\
\hline Grass stage (1) & $\begin{array}{l}\text { Delayed stem elongation, tuft of needles protecting } \\
\text { terminal bud at the ground surface }\end{array}$ & $\mathrm{RCD} / \mathrm{HT}$ ratio & $\begin{array}{l}\text { Keeley and Zedler (1998); } \\
\text { O'Brien et al. (2008); } \\
\text { Rodriguez-Trejo and Fule (2003) }\end{array}$ \\
\hline Bark thickness (2) & Protection of cambial tissue from heat exposure & baBARK/baWOOD ratio & Jackson et al. (1999; Pausas (2015) \\
\hline Self-pruning (3) & $\begin{array}{l}\text { Reducing ladder fuels that enable movement of } \\
\text { fire to tree crown }\end{array}$ & $1 / \mathrm{BB}$ & Keeley and Zedler (1998) \\
\hline Carbohydrate accumulation (4) & $\begin{array}{l}\text { Storage of carbohydrate for allocation to recovery } \\
\text { post-fire }\end{array}$ & TNC concentration & Mims (2015) \\
\hline Protected buds (5) & $\begin{array}{l}\text { Allocation of biomass to needles that may be } \\
\text { consumed during fire }\end{array}$ & $\mathrm{NB} / \mathrm{TB}$ & $\begin{array}{l}\text { Fonda (2001); } \\
\text { Schwilk and Ackerly (2001) }\end{array}$ \\
\hline
\end{tabular}

$H T$ height, $R C D$ root collar diameter, $b a W O O D$ basal area of wood at root collar diameter, $b a B A R K$ basal area of bark at root collar diameter, $B B$ branch biomass, $T N C$ total non-structural carbohydrate, $N B$ needle biomass, $T B$ total biomass 
Seedlings were destructively sampled for biomass measurement in M9 and M13. For each destructive sample, seedlings were divided into main stem, lateral branches, needles, lateral roots, and taproot sections. Samples were oven dried at $80{ }^{\circ} \mathrm{C}$ to reach a constant mass, and weight (within $0.05 \mathrm{~g}$ ) was determined. For the M9 biomass harvest, eight seedlings per species type were selected $(n=40)$. All surviving seedlings were destructively sampled for biomass for the M13 harvest (coastal longleaf pine $n=16$, mountain longleaf pine $n=20$, typical slash pine $\mathrm{n}=20$, south Florida slash pine $n=20$, and loblolly pine $n=16$ ). During the study period, one seedling died of coastal longleaf pine and loblolly pine, and two seedlings died for each mountain longleaf pine, typical slash pine, and south Florida slash pine. On the final harvest date (M13), bark thickness (mm) at the root collar was determined for six randomly selected seedlings per species type $(n=30)$. Bark thickness was determined by measuring the outside and inside bark diameters at three locations on the root collar, with the first measurement point located randomly and the two additional measurements at $45^{\circ}$ and $90^{\circ}$ from the initial measurement point. The three inside and outside bark diameters were averaged, and the inside diameter was subtracted from the outside and divided by two to derive the average bark thickness. Basal area of the area inside bark (basal area of wood; baWOOD) and the basal area of bark (baBARK) were calculated based on the average diameter.

\subsubsection{Needle allocation}

A stratified, simple random sample was taken in M12 (April 2015) to determine the number of needles along the stem, needle density, and needle length for loblolly, typical slash pine, and south Florida slash pine. Longleaf pine was not included because it had no stem elongation. Each seedling was divided into quarters based on their total height that served as the strata [top (1), upper middle (2), lower middle (3), and bottom (4)], with an individual section serving as a sampling unit. Differences in height among species resulted in different quarter section lengths but provide information on the distribution of needle allocation. The stem was divided to reduce variability within sections and account for the variation between sections. We initially sampled three randomly selected individuals by species type to estimate variability in the number of needles within each stratum to determine sampling intensity. The number of units sampled in each stratum was determined using Neyman's optimal allocation formula:

$$
N=\left(\frac{c}{N_{g S g}}\right)
$$

where $N_{g}$ is the number of individuals for the species type for a stratum, and $s_{g}$ is the standard deviation for the type in the stratum of interest.

For each seedling, a randomly located $2 \mathrm{~cm}$ area within the each stratum was delineated. All needles were removed within the delineated area, counted, and measured for needle length. Number of needles per stratum was determined by dividing the number of needles within the $2 \mathrm{~cm}$ sample area by 2 and multiplying by the total length (total number of centimeters) of that portion of the stratum.

\subsubsection{TNC concentration}

The same six seedlings per species type used for bark thickness were also used to determine total non-structural carbohydrate (TNC) concentration in the taproot $(n=30)$. These individuals were harvested in M13. The taproot of each seedling was removed, rinsed to remove any debris, and placed on dry ice until oven-dried (within $2 \mathrm{~h}$ of dissection). Samples were initially oven-dried at $100^{\circ} \mathrm{C}$ for $1 \mathrm{~h}$ to halt any enzymatic processes, then oven-dried at $80^{\circ} \mathrm{C}$ for $48 \mathrm{~h}$, and continued at $60^{\circ} \mathrm{C}$ for an additional 5 days. Taproot samples were then ground to pass through a $0.5-\mathrm{mm}$ sieve and stored in Wheaton $125-\mathrm{ml}$ bottles until the chemical processing was performed.

The TNC concentration within each taproot was determined through extraction using the acid method described by Murphy (1958) and Smith et al. (1964). A 0.3-g sample of each species type was boiled for $2 \mathrm{~h}$ in $40 \mathrm{ml} \mathrm{HCl}(0.2 \mathrm{~N})$, then filtered through No. 2 filter paper into a 100 -ml volumetric flask. Distilled water was used to increase the filtrate to $100 \mathrm{ml}$. A 1$\mathrm{ml}$ aliquot of the filtrate was diluted with $4 \mathrm{ml}$ distilled water, and $1 \mathrm{ml}$ of the dilution and $5 \mathrm{ml}$ anthrone reagent were placed in a test tube. This mixture was heated in a water bath to $95^{\circ} \mathrm{C}$. After heating, the concentration of TNC was measured spectrophotometrically under the wavelength of $627 \mathrm{~nm}$. Carbohydrate concentration was determined from the absorbance of each sample compared to a standard of glucose at $627 \mathrm{~nm}$. The TNC concentration was calculated using the following equation:

$\mathrm{TNC}$ of sample $(\mathrm{mg} / \mathrm{g})=\mathrm{TNC}$ concentration in aliquot $(\mathrm{mg} / \mathrm{ml})^{*} 5(\text { dilution })^{*} 100(\mathrm{ml}) /$ dry weight of root sample $0.3(\mathrm{~g})$ 
Each tap root was processed three times to account for variability within each $0.3 \mathrm{~g}$ sample. The repeated measures were then averaged for each individual to serve as the sampling unit.

\subsection{Data analyses}

To address objective 1, we measured several characteristics of seedling morphology and physiology, including root collar diameter(RCD), height, biomass of needles, stem, branches, lateral roots, and taproot, number of needles by section, average needle density (no. of needles per $\mathrm{cm}$ ), average needle length, bark thickness, and TNC concentration $(\mathrm{mg} / \mathrm{g})$ in the taproot.

Growth data (RCD and height) were compared by month and species type and their interaction using repeated-measures analysis of variance (ANOVA). We used a one-way ANOVA to determine differences among species types for biomass of each seedling section (e.g., needles, stem, branches, lateral roots, and taproot) in M9 and M13 as well as for the proportion of total biomass allocated to each seedling section among species types.

For the six seedlings of each species type randomly selected for TNC concentration within the taproot and bark thickness, we used a one-way ANOVA was used to determine differences among species types. We also used a one-way ANOVA to compare the number of needles per stratum, needle density per centimeter, and needle length for each stratum. A comparison of means was calculated when ANOVA was significant at an alpha of 0.05 using Student's $t$ test. We conducted power analyses to make sure that the variable sample sizes used in the above statistical analyses would be adequate, with results indicating that all our analyses resulted in an actual power greater than 0.99 .

To assess objective 2, the five indices for fire-tolerance traits, we calculated a standardized effect size for each species type as

$S_{i}=\frac{\left(m_{i}-m_{\text {all }}\right)}{m_{\text {all }}}$

where $S_{i}$ is the standardized effect size for species $i, m_{i}$ is the mean estimate for species $i$, and $m_{\text {all }}$ is the mean estimate across all species types. Species types with mean estimates equal to the mean estimate across all species types have standardized effect size of 0 ; positive values of 1 indicate the species type has a mean estimate twice the mean estimate across all species types and negative values of -0.5 indicated the species type has a mean estimate that is half that of the mean estimate across all species types. We used spider graphs to consider the composite expression of these five traits as indication of the degree to which the species types expressed fire-tolerator traits.
Data were analyzed using SAS ${ }^{8}$ 9.1.3 SAS Institute Inc., Cary, NC. Data are reported as means and standard errors of the mean. For seedling biomass variables, data were square root transformed to meet the assumptions of hypothesis testing, but values are reported in original scale to ease interpretability. Any $p$ value less than or equal to 0.05 was considered evidence of a significant difference.

\section{Results}

\subsection{Growth}

Although all species types increased RCD at each measurement time, there were differences in the rate at which they grew (Online Resource 2). Regardless of month, loblolly pine had a significantly smaller RCD than the other species types $(F=832.9 ; p<0.01)$. By M13, south Florida slash pine $(21.1 \pm 0.7 \mathrm{~mm})$ had a significantly larger RCD than mountain longleaf $(19.0 \pm 0.6 \mathrm{~mm})$, typical slash pine $(18.1 \pm 0.4 \mathrm{~mm})$, and coastal longleaf pine $(17.6 \pm 0.4 \mathrm{~mm})$.

Regardless of month, coastal and mountain longleaf pines remained in the grass stage and thus were significantly shorter than other three species types. However, differences in height among the other species types depended on time (Online Resource 3). By M13, loblolly pine $(89.5 \pm 1.6 \mathrm{~cm})$ and typical slash pine $(90.4 \pm 2.8 \mathrm{~cm})$ were similar in height and were both significantly taller than south Florida slash pine $(60.7 \pm 2.7 \mathrm{~cm})$.

\subsection{Biomass allocation}

Total biomass differed among species types in M9 $(F=10.7$; $p<0.01)$ and $\mathrm{M} 13(F=24.8 ; p<0.01)$ (Fig. 1). In M9, typical slash pine had significantly greater biomass than the other species types, while south Florida slash pine, loblolly pine, coastal longleaf pine, and mountain longleaf pine were not different. In M13, typical slash pine and south Florida slash pine had greater total biomass than loblolly pine, mountain longleaf pine, and coastal longleaf pine.

\subsection{Aboveground biomass allocation, needle density, and bark}

Species types differed in their allocation of biomass to aboveground tissues $(F=9.6 ; p<0.01)$, with the greatest aboveground allocation for south Florida slash pine $(72 \pm 2 \%)$. Loblolly pine $(66 \pm 2 \%)$, typical slash pine $(65 \pm 2 \%)$, and mountain longleaf $(63 \pm 2 \%)$ had similar aboveground allocation patterns, and coastal longleaf $(58 \pm 2 \%)$ allocated the least to aboveground tissue growth. 

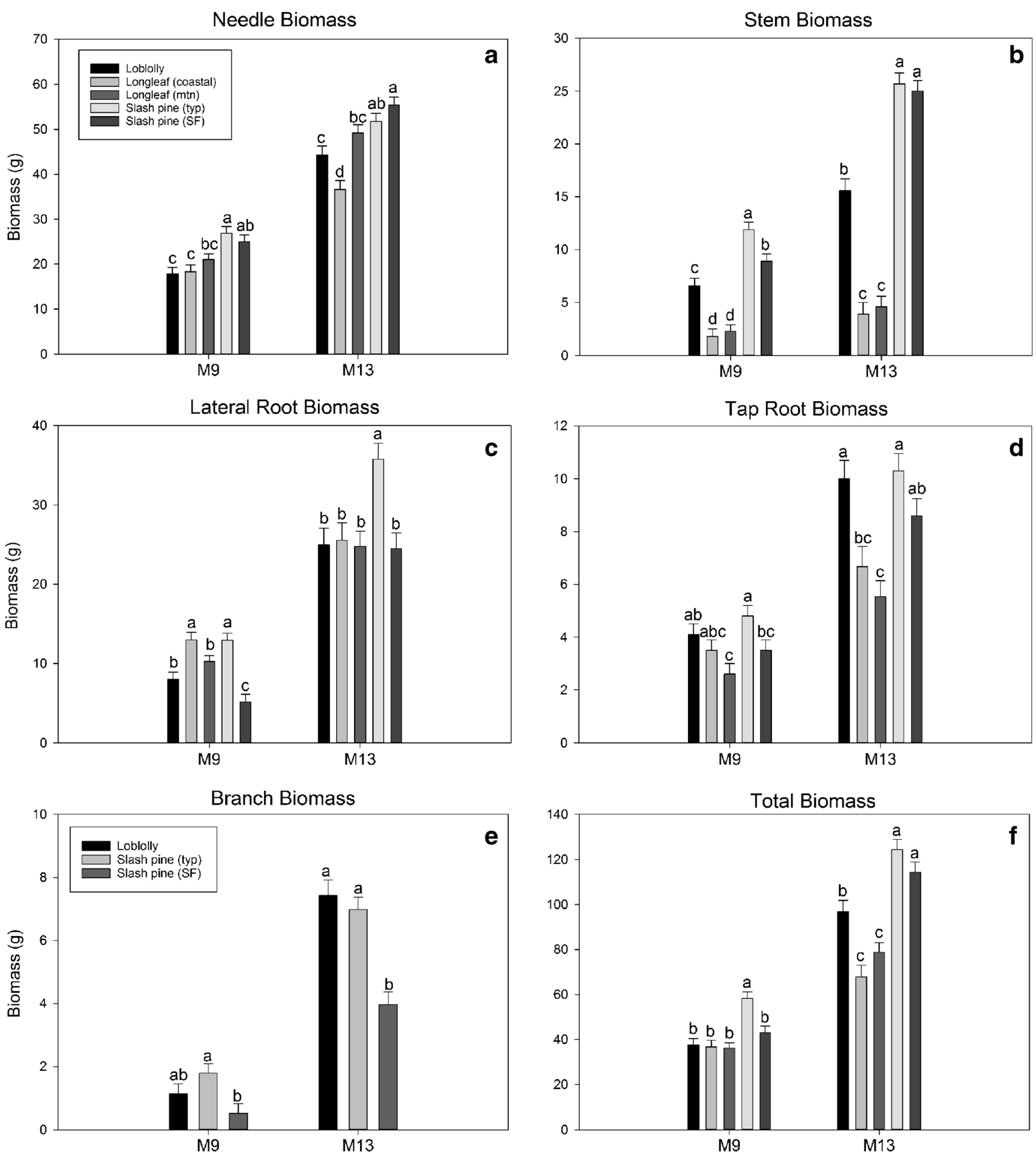

Fig. 1 Differences in biomass [total needle (a), stem (b), lateral root (c), taproot (d), branch (e), and total (f)] among five pine seedling types in month 9 (M9) and month 13 (M13) from planting in greenhouse conditions. Difference in letters indicate a significant difference (alpha $=0.05)$ in species type

Although, the shortest among the three species types with an erect stem, south Florida slash pine, allocated proportionally more aboveground biomass to stem biomass (Table 2). Typical slash pine and south Florida slash pine also had greater stem biomass than loblolly pine (Fig. 1). Average bark thickness at the root collar and the ratio of bark area to wood area differed by species type. Mountain longleaf pine $(4.0 \pm 0.7 \mathrm{~mm})$, south Florida slash pine $(3.9 \pm 0.9 \mathrm{~mm})$, and coastal longleaf pine $(3.4 \pm 0.3 \mathrm{~mm})$ had significantly thicker bark than typical slash pine $(2.2 \pm 0.4 \mathrm{~mm})$ or loblolly pine $(1.4 \pm 0.3 \mathrm{~mm})$. The ratio of bark basal area to wood basal area was significantly higher for mountain longleaf pine 
Table 2 Mean ( \pm SE) proportional (\%) allocation of seedling section (needles, stem, branch, lateral root, and taproot) to total biomass in month 9 (M5) and month 13 (M13)

\begin{tabular}{|c|c|c|c|c|c|c|c|c|c|c|}
\hline \multirow[t]{2}{*}{ Species } & \multicolumn{2}{|l|}{ Needles } & \multicolumn{2}{|l|}{ Stem } & \multicolumn{2}{|l|}{ Branch } & \multicolumn{2}{|c|}{ Lateral Root } & \multicolumn{2}{|l|}{ Taproot } \\
\hline & M9 & M13 & M9 & M13 & M9 & M13 & M9 & M13 & M9 & M13 \\
\hline Loblolly & $47.2(2) b$ & $43.9(2) \mathrm{cd}$ & $17.6(1) b$ & $15.4(1) \mathrm{c}$ & $3.0(0.1) \mathrm{a}$ & $6.7(0.4) \mathrm{a}$ & $21.3(1) \mathrm{c}$ & $23.6(2) \mathrm{cd}$ & $11.0(1)$ & $10.3(1) \mathrm{a}$ \\
\hline Longleaf (coastal) & $49.3(2) b$ & $52.9(2) \mathrm{b}$ & $5.1(1) \mathrm{c}$ & $4.7(1) \mathrm{d}$ & $0(0.3) \mathrm{c}$ & $0(0.4) \mathrm{d}$ & $35.5(1) \mathrm{a}$ & $32.6(2) \mathrm{a}$ & $10.1(1)$ & $9.7(1) a b$ \\
\hline Longleaf (mountain) & $58.4(2) \mathrm{a}$ & $58.4(1) \mathrm{a}$ & $6.4(1) \mathrm{c}$ & $4.7(1) \mathrm{d}$ & $0(0.3) \mathrm{c}$ & $0(0.3) \mathrm{d}$ & $27.9(1) b$ & 29.7 (1)ab & $7.3(1)$ & $7.2(1) \mathrm{c}$ \\
\hline Slash pine (typical) & $46.1(2) b$ & $40.7(1) \mathrm{d}$ & $20.4(1) \mathrm{a}$ & $18.7(1) b$ & $2.9(0.3) \mathrm{a}$ & $5.5(0.3) \mathrm{b}$ & $22.2(1) \mathrm{c}$ & $26.6(2) b c$ & $8.3(1)$ & 8.5 (1)abc \\
\hline Slash pine (South Florida) & $60.0(2) \mathrm{a}$ & $46.6(1) \mathrm{c}$ & $19.7(1) \mathrm{ab}$ & $22.2(1) \mathrm{a}$ & $1.2(0.3) \mathrm{b}$ & $3.0(0.3) \mathrm{c}$ & $11.3(1) \mathrm{d}$ & $20.6(2) \mathrm{d}$ & $7.8(1)$ & $7.7(1) b c$ \\
\hline
\end{tabular}

Statistical significance (alpha $=0.05$ ) was determined using an ANOVA within strata across species type. Significant differences between species types were determined using pairwise comparisons and are indicated by differences in lowercase letters

$(0.46 \pm 0.1)$, coastal longleaf pine $(0.42 \pm 0.1)$, and south Florida slash pine $(0.38 \pm 0.2)$ compared to either typical slash pine $(0.08 \pm 0.03)$ or loblolly pine $(0.05 \pm 0.01)$. Loblolly pine and typical slash pine allocated proportionally more to lateral branching than south Florida slash pine (Table 2). Additionally, the total amount of branch biomass of loblolly pine and typical slash pine was greater than south Florida slash pine (Fig. 1).

Mountain and coastal longleaf pines allocated proportionally more biomass to needles than the other species types (Table 2). However, total needle biomass was greatest for south Florida slash pine and typical slash pine, followed by mountain longleaf pine (Fig. 1). Loblolly pine had the second lowest needle biomass followed by coastal longleaf pine.

Loblolly pine had significantly fewer needles in the top stratum and significantly more needles in the bottom stratum than either typical or south Florida slash pines (Table 3). South Florida slash pine had significantly more needles in the upper middle stratum than loblolly pine or typical slash pine. South Florida slash pine had greater density of needles in the top and upper middle stratum than either loblolly pine or typical slash pine. Typical slash pine did not have needles on the lower stratum. South Florida slash pine
Table 3 Average abundance of needles (mean $\pm \mathrm{SE}$ ), average density (no. of needles per $\mathrm{cm}$ ), and average needle length $(\mathrm{cm})$ per strata (top, upper middle, lower middle, and bottom) by species type

\begin{tabular}{llll}
\hline Species & Abundance (SE) & Density (SE) & Length (SE) \\
\hline & Top & & \\
Loblolly & $148.2(51.3) \mathrm{b}$ & $10.3(4.2) \mathrm{b}$ & $5.9(1.9)$ \\
Slash pine (typical) & $306.6(34.2) \mathrm{a}$ & $17.1(2.8) \mathrm{b}$ & $6.9(1.3)$ \\
Slash pine (south Florida) & $288.7(29.6) \mathrm{a}$ & $28.0(2.4) \mathrm{a}$ & $9.5(1.1)$ \\
& $p=0.045$ & $p=0.002$ & $p=0.164$ \\
Loblolly & Upper middle & & $11.2(3.6) \mathrm{b}$ \\
Slash pine (typical) & $204.3(54.5) \mathrm{b}$ & $13.5(4.5) \mathrm{b}$ & $15.9(2.4) \mathrm{b}$ \\
Slash pine (south Florida) & $276.0(35.7) \mathrm{b}$ & $15.6(2.9) \mathrm{b}$ & $24.5(2.4) \mathrm{a}$ \\
& $399.5(35.7) \mathrm{a}$ & $37.9(2.9) \mathrm{a}$ & $p=0.015$ \\
Loblolly & $p=0.018$ & $p<0.001$ & $19.6(0.5) \mathrm{b}$ \\
Slash pine (typical) & Lower middle & & $25.1(0.5) \mathrm{a}$ \\
Slash pine (south Florida) & $256.1(33.0)$ & $16.1(2.0) \mathrm{b}$ & $26.3(0.9) \mathrm{a}$ \\
& $356.7(33.0)$ & $19.6(2.0) \mathrm{ab}$ & $p<0.001$ \\
Loblolly & $282.5(61.7)$ & $27.9(3.7) \mathrm{a}$ & $19.0(3.0) \mathrm{a}$ \\
Slash pine (typical) & $p=0.109$ & $p=0.030$ & $0(3.3) \mathrm{b}$ \\
Slash pine (south Florida) & Bottom & & $25.4(2.2) \mathrm{a}$ \\
& $145.4(25.8) \mathrm{a}$ & $9.5(2.1) \mathrm{a}$ & 0.001 \\
\hline
\end{tabular}

Statistical significance $($ alpha $=0.05)$ was determined using an ANOVA within strata across species types and significant is indicated by italics. Significant differences between species types were determined using pairwise comparisons and are indicated by differences in lowercase letters 
had longer needles on the upper middle stratum compared to both loblolly and typical slash pine. Loblolly pine had shorter needles on the lower stratum than either slash pine type.

\subsection{Belowground biomass allocation and TNC concentration}

Loblolly pine allocated significantly more biomass to the taproot than mountain longleaf pine and south Florida slash pine (Table 2). Similarly, south Florida slash pine, typical slash pine, and coastal longleaf pine allocated more to taproot biomass than mountain longleaf. Total taproot biomass also differed by species type (Fig. 1). Typical slash pine, loblolly pine, and south Florida slash pine had similar taproot biomasses. However, south Florida slash pine was also similar to coastal longleaf. Mountain longleaf had the smallest taproot biomass and was similar to coastal longleaf.

Total non-structural carbohydrate concentrations in taproots were significantly different by species type $(F=10.3 ; p<0.001)$ (Fig. 2). Mountain longleaf pine, coastal longleaf pine, and south Florida slash pine had significantly greater concentrations of TNC in taproots than typical slash pine or loblolly pine.

\subsection{Expression of fire-adaptation traits}

The standardized effect size for each of the five fire adaptation indices provided a comparison of the strength of trait expression relative to the mean among the studied species types (Fig. 3; Online Resource 4). The composite of the standardized effect sizes for these five indices suggests that the two longleaf pine types have the strongest expression of fire tolerance, followed by south Florida slash pine, typical slash pine, and loblolly pine. Bark thickness (i.e., calculated as the standardized ratio of basal area in bark to the basal area in wood) and non-structural carbohydrate traits were most strongly expressed by both longleaf pine types and south Florida slash pine, and the two longleaf pine types most strongly expressed the grass stage and low branching adaptation. There was relatively low variability among the five species types for the ratio of needle biomass to total biomass, as an expression of foliage production to protect buds from heat damage from fire.

\section{Discussion}

The variation in fire frequency has been an important driver in the distribution and abundance of southern pines. It is widely acknowledged that a fire frequency of $1-5$ years is associated with the historical dominance of longleaf pine in southern coastal plains (Frost 1998). With longer fire-return intervals or fire suppression, loblolly pine and other hardwood species will replace longleaf pine as a dominant species in the northern coastal plains, and further south, typical slash pine may become favored (Agee 1998). Loblolly pine and typical slash pine readily invade longleaf pine stands due to their frequent and abundant seed production, rapid early growth, and ability to withstand fire after the sapling stage (Lohrey and Kossuth 1990). Where longleaf pine and south Florida slash pine overlap in range, they are often found co-occurring in transition zones. While these patterns in the distribution and abundance of southern pines are commonly discussed in association with fire regimes, few studies have directly quantified the morphology and physiology of southern pine seedlings to describe fire tolerance.

Although generally considered "fire tolerators," our results clearly indicated that southern pines differ in their fire adaptations during the seedling stage, resulting in markedly different strategies for regeneration success. In some cases, species considered fire tolerators at maturity (i.e., thick bark, selfpruning, and canopy recovery from scorch) may actually represent different fire-adaptive strategies (i.e., fire-refugia species) when early life stages are also considered. For example,
Fig. 2 Total non-structural carbohydrate (TNC) concentration in the taproot of pine seedling types grown in greenhouse conditions. Total nonstructural carbohydrate concentration was determined 13 months since planting (M13). Significant differences between species types are indicated by differences in letters

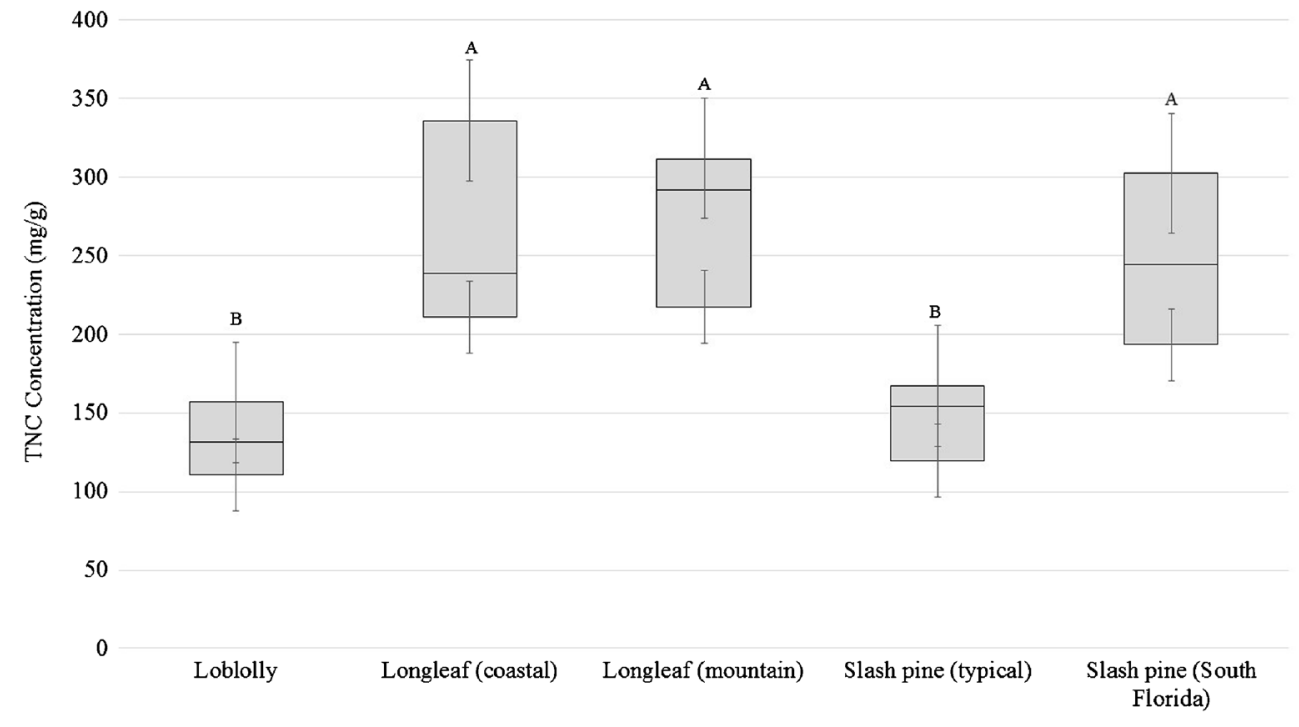



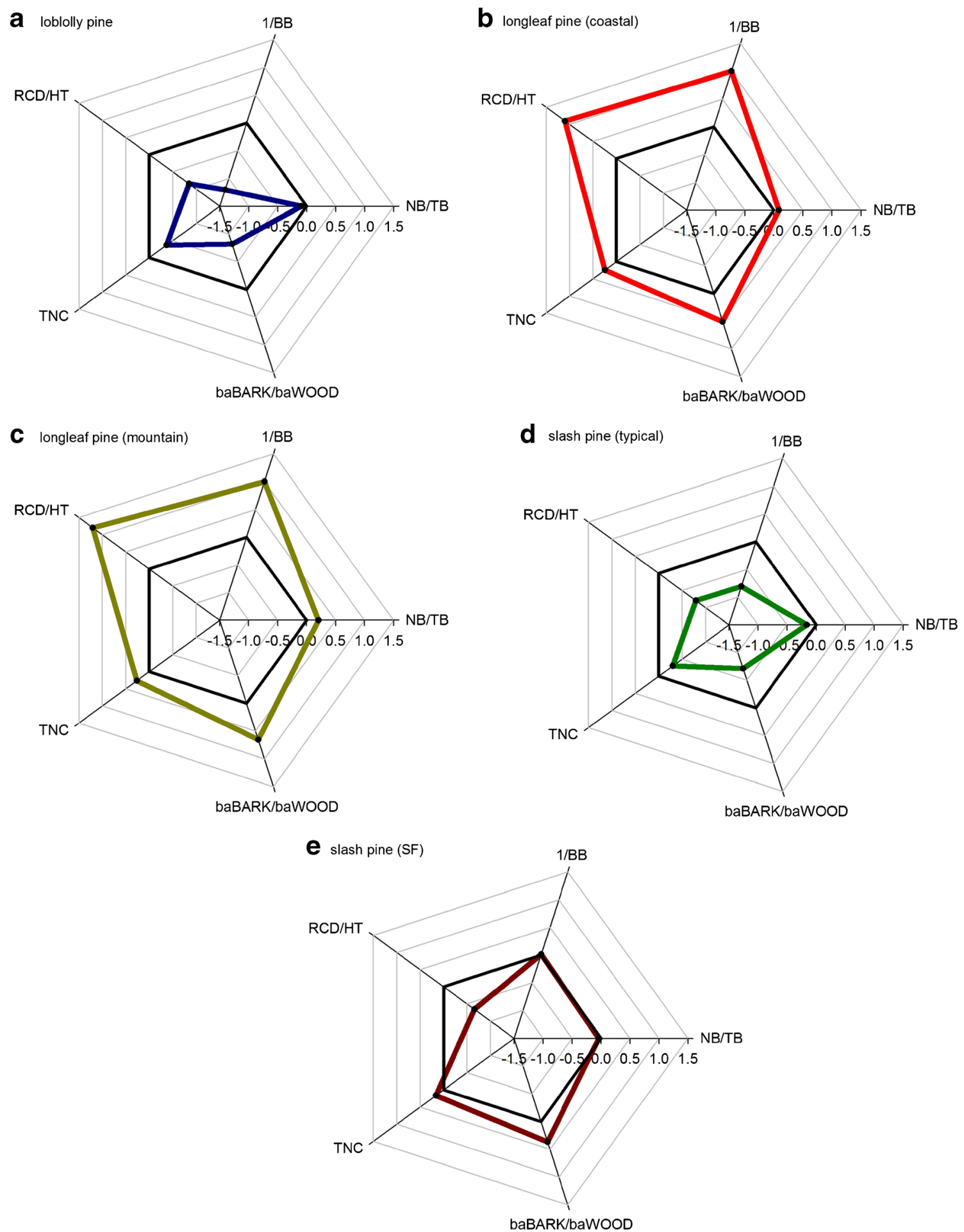

Fig. 3 Allocation of fire-tolerance traits by species type. Solid black line represents the standardized average allocation across species type [branch and needle biomass; root collar diameter divided by total height (RCD/

HT); total non-structural carbohydrates in the taproots (TNC); ratio of basal area of bark to basal area of wood at root collar diameter (baBARK/baWOOD)]

mature loblolly pine and slash pine are tolerant to fire from the development of thick bark with tree age and less susceptibility to mortality from crown scorch (Allen 1960; Wright and Bailey 1982). However, when loblolly pine is less than 9 years old, $25 \%$ needle consumption can result in over $75 \%$ mortality

(Ferguson 1955). Within a frequently burned landscape, unburned patches may act as a refugia for seeds and seedlings of loblolly and typical slash pines.

One of the most striking fire adaptation traits in Pinus is the grass stage. The grass stage has been characterized as delayed 
development of the stem, where internode elongation is suppressed during early growth (up to more than 10 years) to create the appearance of a bunchgrass growth form (Keeley and Zedler 1998; Rodriguez-Trejo and Fule 2003; Wahlenberg 1946). Because seedlings in the grass stage are vulnerable to competition (Wahlenberg 1946), this strategy is largely restricted to oligotrophic substrates where frequent, low-intensity fires prevail (Keeley 2012). Despite the resource requirements from the frequent consumption of aboveground foliar tissue, longleaf is able to persist due to the fire-adapted traits associated with the grass-stage growth strategy.

Our results confirmed that seedlings of longleaf pine, both coastal and mountain, remained stemless, whereas south Florida slash pine, even as a recent germinant, had an erect stem similar to typical slash pine and loblolly pine (Fig. 4). South Florida slash pine has been documented to have a grass stage similar to longleaf pine (Lohrey and Kossuth 1990), but previous descriptions suggest it may be less pronounced than that of longleaf pine (Mirov 1967; Perry et al. 1998). Our findings show that young south Florida slash pine seedlings do not remain stemless (i.e., lack of a true grass-stage) but express many traits, similar to longleaf pine, which allow it to persist under similar fire return intervals. This finding highlights that (1) the grass stage, although used to exemplify fire adaptation of pine seedlings, may be considered to be the expression of a suite of fire adaptation traits, and (2) the strength of expression of fire adaptation traits occur along a continuum among species. Although our study did not evaluate naturally regenerated seedlings in the field nor sampled seeds from all possible populations, it is unlikely that south Florida slash pine would develop a true grass stage in the field because the grass-stage trait is genetically controlled (i.e., Nelson et al. 2003; Pausas 2015).

The density and arrangement of needles around the stem and apical bud may provide a protective mechanism against heat for sensitive tissues (Chapman 1947; Wahlenberg 1946). During the grass stage, needles are decumbent and insulate the apical bud from the heat of surface fires (Rodriguez-Trejo and Fule 2003). Although south Florida slash pine does not have a grass stage, it has the greatest needle density on the top two thirds of the stem compared to typical slash pine and loblolly pine. In addition, like longleaf pine, south Florida slash pine also has highly flammable needles (Fonda 2001), supporting frequent surface fires that burn quickly and completely and reduce the heating residence time experienced by seedlings. Furthermore, lack of branching in sapling stage longleaf pine has also been attributed to the reduced potential for crown fires at juvenile stages (Chapman 1932). Therefore, the significantly less lateral branching in south Florida slash pine, compared to typical slash pine and loblolly pine, may also benefit seedling survival. The reduced height growth and lack of branch development when combined with dense and long needles may create the grass-stage appearance of south Florida slash pine.

Bark thickness in fire-prone ecosystems has been proposed to increase species fitness, and the variability seen in bark thickness may be related to the variability of fire regimes (Pausas 2015). Species adapted to frequent surface fire regimes favor early investment in bark over allocation to wood (Jackson et al. 1999), as demonstrated by both longleaf pine types and south Florida slash pine. Similar patterns in bark thickness among co-genera species are seen in Quercus, where species with thick bark are associated with surface fire regimes (Zedler 1995). Bark thickness of 5 to
Fig. 4 From left to right: typical slash pine; loblolly pine; south Florida slash pine, and longleaf pine (coastal). Photo taken August 24, 2014. Individuals were selected at random

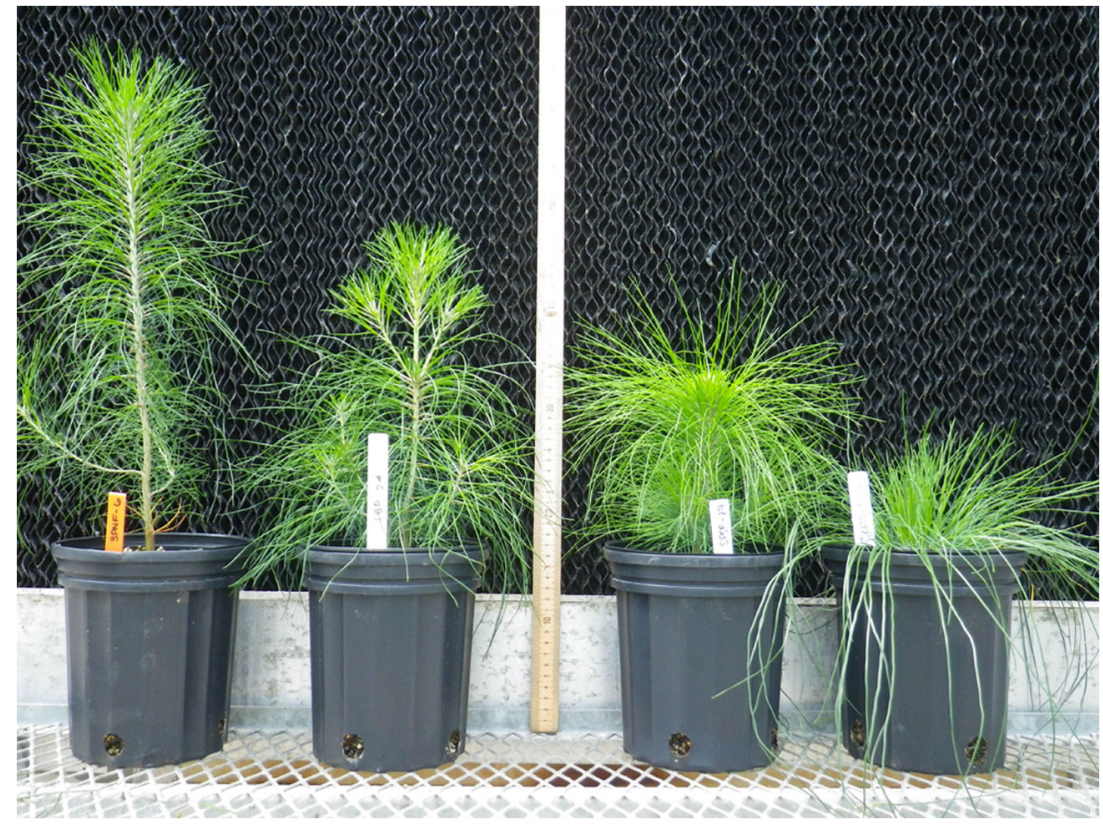


$10 \mathrm{~mm}$ may provide enough insulation to the cambium to survive surface fire (Harmon 1984). After 1 year of growing in greenhouse conditions, bark thickness of both longleaf pines and south Florida slash pine approached $4 \mathrm{~mm}$, twice as thick as typical slash and loblolly pine.

Belowground storage non-structural carbohydrates by grassstage longleaf pines has been suspected to provide energy for rapid height growth following grass-stage emergence (Wahlenberg 1946). Non-structural carbohydrate storage may also assist recovery from damage to aboveground tissue during regrowth of foliage or stem tissue (e.g., sprouting) (Bowen and Pate 1993; Guo et al. 2004; Miyanishi and Kellman 1986). However, a recent study has demonstrated that growing tall is not an effective strategy for longleaf pine saplings to survive fire (Wang et al. 2015). Thus, the greater concentrations of nonstructural carbohydrates in south Florida slash pine and longleaf pine may ensure recovery of photosynthetic tissue following frequent fire (Knapp et al. submitted; Kuehler et al. 2006) rather than support rapid growth during the emergence from the grass stage.

\section{Conclusion}

Species-specific fire adaptation interact with characteristics of the fire regime to affect tree regeneration pathways. The suite of traits expressed by coastal and mountain longleaf pine and south Florida slash pine suggest they fit as fire tolerators that can survive very frequent surface fires in the seedling stage. In contrast, loblolly pine and typical slash pine tolerate fire when mature, but represent fire-refugia species that act as a source population for regeneration during longer fire-free intervals, whether at local or landscape-scales. Fine-scale variability in fuels or fire behavior may allow regeneration of either species to occur within similar sites and fire regimes, but our results suggest that different regeneration strategies based on fire frequency are defined by seedling traits. Seedlings of longleaf and south Florida slash pine represent a persistence strategy where resources are allocated to protective mechanisms. In contrast, longer fire-return intervals or areas with unburned patches would likely favor typical slash pine and loblolly pine because they can allocate resources to height growth, which may have allowed the persistence of the two species, albeit in limited abundance, in a region characterized by a frequent surface fire regime. In the absence of fire, these species would also capitalize through rapid expansion. Although we assume that the traits described in this study are important for fire tolerance, the relative importance of each individual trait remains unknown and calls for further investigations.

Acknowledgements We would like to thank Roberta Sanasac, Eric Winters, Carlee Steppe, Carissa Adams, and Hannah Spencer for their assistance in the greenhouse; Additionally, Jimmy Lisenby of the Taylor Tree Nursery for his guidance on planting materials and nursery practices, Wayne Chao for his assistance with the TNC procedures, and Amith Maroli for his laboratory assistance. We would also like to thank Dr.
Martin L. Cipollini of Berry College and Steve Gilly of the Andrews Nursery for providing the seed source for this study.

Funding information This material is based upon work supported by the NIFA/USDA, under project number SC-1700508.

\section{References}

Agee JK (1998) Fire and pine ecosystems. In: Richardson DM (ed) Ecology and biogeography of Pinus. Cambridge University Press, Cambridge, pp 193-218

Allen PH (1960) Scorch and mortality after a summer burn in loblolly pine Res Note No 144 Asheville, NC: US Department of Agriculture, Forest Service, Southeastern Forest Experiment Station $2 \mathrm{p}$

Bowen BJ, Pate JS (1993) The significance of root starch in post-fire shoot recovery of the resprouter Stirlingia latifolia R. Br. (Proteaceae). Ann Bot 72:7-16. https://doi.org/10.1006/anbo.1993.1075

Brown JK, Smith JK (2000) Wildland fire in ecosystems: effects of fire on flora Gen Tech Rep RMRS-GTR-42-vol 2 Ogden: US Department of Agriculture, Forest Service, Rocky Mountain Research Station 257 p

Chapman HH (1932) Is the longleaf type a climax? Ecology 13:328-334

Chapman HH (1947) Results of a prescribed fire at Urania, La., on longleaf pine land. J For 45:121-123

Ferguson ER (1955) Fire-scorched trees - will they live or die? In: Modern forest fire management in the south: Proceedings, 4th annual forestry symposium, Baton Rouge, April 6-7, 1955. Louisiana State University, General Extension Division, School of Forestry, pp 102-113

Fonda RW (2001) Burning characteristics of needles from eight pine species. For Sci 47:390-396

Frost CC (1998) Presettlement fire frequency regimes of the United States: a first approximation. In: Pruden TL, Brennan LA (eds) Fire in ecosystem management: shifting the paradigm from suppression to prescription Tall Timbers Research Station, Tallahassee. Tall Timbers Fire Ecology Conference Proceedings, pp 70-81

Frost CC (2006) History and future of the longleaf pine ecosystem. In: Jose S, Jokela EJ, Miller DL (eds) Fire in ecosystem management: shifting the paradigm from suppression to prescription, vol Tall Timbers Fire Ecology Conference Proceedings, No. 20. Tall Timbers Research Station, Tallahassee, pp 70-81

Guo DL, Mitchell RJ, Hendricks JJ (2004) Fine root branch orders respond differentially to carbon source-sink manipulations in a longleaf pine forest. Oecologia 140:450-457. https://doi.org/10. 1007/s00442-004-1596-1

Harmon ME (1984) Survival of trees after low-intensity surface fires in Great Smoky Mountains National Park. Ecology 65:796-802

Jackson JF, Adams DC, Jackson UB (1999) Allometry of constitutive defense: a model and a comparative test with tree bark and fire regime. Am Nat 153:614-632. https://doi.org/10.1086/303201

Keeley JE (2012) Ecology and evolution of pine life histories. Ann For Sci 69:445-453. https://doi.org/10.1007/s13595-012-0201-8

Keeley JE, Zedler PH (1998) Evolution of life histories in Pinus. In: Richardson DM (ed) Ecology and Biogeography of Pinus. Cambridge University Press, Cambridge, pp 219-249

Knapp BO, Pile LS, Walker JL, Wang GG (submitted) Fire effects on a fire-adapted species: response of grass-stage longleaf pine seedlings to experimental burning. Fire Ecology

Kuehler EA, Sword Sayer MA, Andries CD (2006) How does fire affect longleaf pine root carbohydrates, foliar nutrients, and sapling growth? In: Connor KF (ed) Proceedings of the 13th Biennial Southern Silvicultural Conference, Asheville. vol Gen. Tech. Rep. SRS-92. Department of Agriculture, Forest Service, Southern Research Station, pp 98-101 
Lohrey RE, Kossuth SV (1990) Slash pine (Pinus elloittii Engelm.), vol 2. Agriculture Handbook 654. U.S. Department of Agriculture, Forest Service, Washington, DC 877 p

Millar CI (1998) Early evolution of pines. In: Richardson DM (ed) Ecology and biogeography of Pinus. Cambridge University Press, Cambridge, pp 69-91

Mims JT (2015) Nonstructural carbohydrate concentrations of pine trees as a function of evolutionary history. Georgia Southern University, Statesboro

Mirov NT (1967) The genus Pinus. Ronald Press, New York

Miyanishi K, Kellman M (1986) The role of root nutrient reserves in regrowth of two savanna shrubs. Can J Bot 64:1244-1248. https:// doi.org/10.1139/b86-171

Murphy RP (1958) Extraction of plant samples and the determination of total soluble carbohydrates. J Sci Food Agric 9:714-717

Nelson CD, Weng C, Kubisiak TL, Stine M, Brown CL (2003) On the number of genes controlling the grass stage in longleaf pine. J Hered 94:392-398. https://doi.org/10.1093/jhered/esg086

O'Brien JJ, Hiers JK, Callaham MA, Mitchell RJ, Jack SB (2008) Interactions among overstory structure, seedling life-history traits, and fire in frequently burned neotropical pine forests. AMBIO: A J Hum Environ 37: 542-547. https://doi.org/10.1579/0044-7447-37.7.542

Pausas JG (2015) Bark thickness and fire regime. Funct Ecol 29:315327. https://doi.org/10.1111/1365-2435.12372

Peet RK (2006) Ecological classification of longleaf pine woodlands. In: Jose S, Jokela EJ (eds) The longleaf pine ecosystem: ecology, Silviculture, and restoration. Springer Science + Business Media, New York, pp 51-93
Perry JP, Graham A, Richardson DM (1998) The history of pines in Mexico and central America. In: Richardson DM (ed) Ecology and biogeography of Pinus. Cambridge University Press, Cambridge, pp 137-152

Rodriguez-Trejo DA, Fule PZ (2003) Fire ecology of Mexican pines and a fire management proposal. Int J Wildland Fire 12:23-37. https:// doi.org/10.1071/WF02040

Schultz RP (1999) Loblolly - the pine for the twenty-first century. New Forest 17:71-88

Schwilk DW, Ackerly DD (2001) Flammability and serotiny as strategies: correlated evolution in pines. Oikos 94:326-336. https://doi.org/10. 1034/j.1600-0706.2001.940213.x

Smith D, Paulsen GM, Raguse CA (1964) Extraction of total available carbohydrates from grass and legume tissue. Plant Physiol 39:960-962

Squillace AE (1966) Geographic variation in slash pine Forest Science Monograph 10

Wahlenberg WG (1946) Longleaf pine: its use, ecology, regeneration, protection, growth, and management. Charles Lathrop Pack Forestry Foundation and USDA Forest Service, Washington, DC

Wang GG, Pile LS, Knapp BO, Hu H (2015) Longleaf pine adaptation to fire: is early height growth pattern critical to fire survival? In: Schweitzer CJ, Clatterbuck WK, Oswalt CM (eds) Proceedings of the 18th Biennial Southern Sivicultural Research Conference, Knoxville, TN. US Forest Service, Southern Research Station. eGen. Tech Rep SRS-212. 5 p

Wright HA, Bailey AW (1982) Fire ecology: United States and southern Canada. Wiley, New York

Zedler PH (1995) Are some plants born to burn? Trends Ecol Evol 10: 393-395. https://doi.org/10.1016/S0169-5347(00)89153-3 